\title{
How Did Xuanzang Understand Dhäranì?: A View from His Translations
}

RICHARD D. MCBRIDE II

Brigham Young University

richard_mcbride@byu.edu

Abstract: Xuanzang's 玄牀 (ca. 602-664) chanting the Heart Sütra and its spell for protection throughout his famed journey to the Indian kingdoms is well known. What is not well known is that in his biography recorded by his colleague Daoxuan 道宣 (596-667) in Further Lives of Eminent Monks (Xu Gaoseng zhuan 續高僧傳), his translation of the Sütra on the Six Approach Spirit Spell (Liumen shenzhou jing 六門神呪經; aka Sütra on the Six Approach Dhäranī [Liumen tuoluoni jing 六門陀羅尼經; Skt. Sanmukbidhärani]]) is listed among his important works and translations. Not counting his translation of the Heart Sütra, Xuanzang translated nine dhärañ texts that have been preserved in the Koryŏ Buddhist Canon (and hence the Taishō Canon). Among these are arguably the earliest translations of the dhārañis associated with Amoghapāśa, the lasso-wielding form of Avalokiteśvara, and the Eleven-Headed form of Avalokiteśvara. Because all translations are interpretations, something of Xuanzang's view of dhäranī is preserved in these materials. Just as important, Xuanzang's understanding of dhārani was shaped by the translations he made. As his disciple Yancong's 彥悰 (d. after 688) preface emphasizes, dhārañi (spell techniques or spellcraft; zhoushu 呪術), along with the practice of meditation and the observance of monastic discipline, is but one of the myriads of mainstream Buddhist ways leading to the one goal of dispelling illusion and benefiting living beings. 
Keywords: Xuanzang, dhārañī, dhārañī sütras, translations, thisworldly benefits, healing rituals, fire rituals (homa), bodhisattva practices

DOI: https://dx.doi.org/10.15239/hijbs.03.01.09

X uanzang's constant recollection of the Bodhisattva Avalokiteśvara and chanting of the Heart Sütra, including its spell for protection, throughout his famed journey to the Indian kingdoms is well known. ${ }^{1}$ What is not well known is that in his biography recorded by his colleague Daoxuan 道宣 (596-667) in Further Lives of Eminent Monks (Xu Gaoseng zhuan 續高僧傳), his translation of the Sütra on the Six Approach Spirit Spell (Liumen shenzhou jing 六門神 呪經; aka Sütra on the Six Approach Dhāranī [Liumen tuoluoni jing 六門陀羅尼經; Skt. Sanmukhidhāranī]) is listed among his important works and translations. ${ }^{2}$ Xuanzang's disciple and biographer, Yancong 彥悰 (d. after 688), mentions the Sütra on the Six Approach

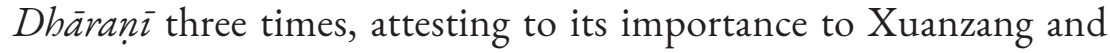
his school. In addition, Xuanzang reportedly made a thousand hand copies of his translations of the dhärañi, the Diamond Sütra (Nengduan bore 能斷般若), and the Bhaisajyaguru Sütra (Yaoshi 藥 師), along with a thousand painted images and ten clay images of Maitreya. ${ }^{3}$ Not counting his translation of the Heart Sütra (Bore boluomiduo xin jing 般若波羅蜜多心經, $T$ no. 251), Xuanzang is

1 Da Tang Da Ci'en si sanzang fashi zhuan, T no. 2053, 50: 1.224b7-8; cf. Li, trans., A Biography, 26. Waley, The Real Tripitaka and Other Pieces, 17, 19, and 98; Ch'en, Buddhism in China, 235; Wriggins, Xuanzang, 119-20; Nattier, 'The Heart Sūtra'.

$2 X u$ Gaoseng zhuan, $T$ no. 2060, 50: 4.455a24; cf. it is referred to as the Liumen tuoluoni jing, T no. 1360, 21: 1.878a.

3 Da Tang Da Ci'en si sanzang fashi zbuan, $T$ no. 2053, 50: 6.254a6-11; Tno. 2053, 50: 6.254a24-28; and T no. 2053, 50: 10.276c24-277a10. 
associated with nine dhärañ texts that have been preserved in the Koryŏ Buddhist Canon (and hence the Taishō Canon). Because all translations are interpretations, something of Xuanzang's views on dhārañ $\bar{a}$ are preserved to a certain extent in these materials. Just as important, Xuanzang's understanding of dhärañi was shaped by the translations he made.

How did Xuanzang, the famed pilgrim, translator, proponent of Yogācāra Buddhism, and devotee of the bodhisattvas Avalokiteśvara and Maitreya, understand dhäranit? To accomplish this purpose, I translated seven of the eight extant translations of $d$ härañ $\bar{u}$ utras by Xuanzang. For this study I did not translate the *Amoghapaśahrdaya or Sütra on the Heart of the Spirit Spell of Amoghapāsa (Bukong juansuo shenzhou xin jing 不空罱索神咒心經, T no. 1094). One other remaining spell text, Five Spells (Zhou wu shou 咒五首, T no. 1034), is a list of five dhärañ re-transliterated by Xuanzang in 664, as his last translation prior to his death. Because there are no procedures or explanations of the benefits of use, only the names of spells, I do not examine it in this study.

A close reading of these seven spell sütras translated by Xuanzang suggests that the famous translator recognized three interrelated purposes of dhärañī: (1) providing benefits and bliss to living beings; (2) furnishing a proficient means of dealing with demonic, illness-causing entities; and (3) producing conditions conducive to advancement on the bodhisattva path. All of Xuanzang's translations of dhärani texts function like simple ritual manuals that emphasize the efficacy of the dharani introduced in the text. In Xuanzang's translations, dhärani $\bar{i}$ did not function as codes that encapsulate the doctrine of a sütra, they were powerful and efficacious spells and incantations. His translations are primarily straight-forward and simple ritual texts that encourage the preservation and recitation of a particular dhäranī. Of these, Xuanzang's translations of the *Avalokitesvaraikādasamukha-dhārañi or Sütra on the Heart of the Spirit Spell of the Eleven-Headed Avalokitesvara (Shiyimian shenzhou xin jing 十一面神呪心經, T no. 1071) and the Sütra on the Heart of the Spirit Spell of Amoghapāsa, however, preserve more detailed observances. Xuanzang's understanding of dhäran̄i ritual for treating demonic and other forms of illness was broad enough to 
include elementary fire rituals (boma). Xuanzang's understanding of dhärañ $\bar{\imath}$ fleshes out my previous research and provides important insight and evidence supporting the view that $d \bar{a} \bar{r}$ ran $\bar{\imath}$ were mainstream Mahāyāna Buddhism in seventh-century East Asia. ${ }^{4}$

As one of the most important proponents of doctrinal Buddhism in seventh-century East Asia, Xuanzang was certainly familiar with the classification of a $d h \overline{a r a n} \bar{\imath}$ that might function like a mnemonic device to encapsulate or encode the doctrinal significance of a sütra. Dhāraṇi are defined broadly in mainstream Mahāyāna literature as being comprised of four types: 'dharma dhäran $\vec{\imath}$ ( fa tuoluoni 法陀 羅尼), 'meaning dhāran $\vec{\imath}$ (yi tuoluoni 義陀羅尼), 'spell or spell-technique dhäran $\vec{\imath}$ (zhou tuoluoni 呪陀羅尼), and 'acquiescence dhäran $\vec{\imath}$ (ren tuoluoni 忍陀羅尼). Xuanzang deploys this set of four types of dhārañi in his seminal Chinese translation of the Yogàcārabbūmi (Yuqie shidi lun 瑜伽十地論, T no. 1579), following earlier translations and exegesis, including Dharmakșema's (Tanwuchen 昙無 識, 385-433) translation of the Bodhisattvabhümi (Pusa dichi jing 菩薩地持經， $T$ no. 1581) and Bodhiruci's (Putiliuzhi 菩提流支, fl. 508-527) translation of ${ }^{*}$ Daśabbümika-sūtra-śāstra (Shidijing lun 十地經論, $T$ no. 1522) (See Table 1: Classifications of Dhärani in Exegesis). Of these four classifications employed commonly and conventionally by Xuanzang and others, the first two correspond to the strict definition of $d$ ba rañ $\bar{\imath}$ commonly held by some modern scholars who regard dhärañ $\bar{i}$ as mnemonic codes that enable one to maintain or preserve large amounts of the Buddhist teaching in one's memory. ${ }^{5}$ In this respect they are powerful because of the link forged with the preservation of Buddhist sütras, the word of the Buddha. The fourth, acquiescence dhärañi, are the adornment of all bodhisattvas since they abide peacefully with all dharmas, knowing the great secret-which is the esoteric teaching of the Mahāyāna

4 See, for instance, McBride, 'Dhāraṇī and Spells in Medieval Sinitic Buddhism'; 'Practical Buddhist Thaumaturgy'; and 'Wish-fulfilling Spells and Talismans'.

5 See Braarvig, 'Dhāraṇī and pratibhāna'; Davidson, 'Studies in Dhāraṇ̄ Literature I' and 'Studies in Dhārañī Literature II'. 
and which is only intelligible to true bodhisattvas-that all dharmas are neither produced nor destroyed and that they are all originally quiescent (nirvāna). The third kind, 'spell technique' dhāraṇi, or mantra-dhärañ in Sanskrit, is important because, in my opinion, it demonstrates that in early medieval Sinitic Buddhism (ca. 317-907) the concept of $d$ barani had subsumed mantra, which are found in all Indian religions. All of the dhäranī translated by Xuanzang fall into this third category.

\section{Benefits and Bliss}

The most prominent recurring theme in Xuanzang's translations of $d \bar{b} \bar{r} r a n \bar{\imath}$ is the idea that $d \bar{a} \bar{a} r a n \bar{\imath}$ are preached and their associated procedures are explained for the benefit of and to invoke or cause peace and bliss for all living beings. The Sütra on the Six Approach Dhärañi (Liumen tuoluoni jing 六門陀羅尼經, $T$ no. 1360), for instance, begins with the Buddha making the following assertion: ' $O$ good sons, if you desire to benefit and give peace and bliss to living beings, you should receive the procedure of this dhârañ in six approaches' (爾時世尊告諸菩薩. 善男子若欲利益安樂眾生. 汝當受此六 門陀羅尼法). ${ }^{6}$ Further developing this theme, Xuanzang's translation of the Sütra on the Dhärañ for Bearing Banners and Seals (Sheng chuangbeiyin tuoluoni jing 勝幢臂印陀羅尼經, $T$ no. 1363) reports that Mahābrahmā and a heavenly throng respectfully addressed the Buddha with the following question:

O World-Honored One, because we desire [to give] benefits and bliss to all sentient beings, we seek to realize unsurpassed, perfect bodhi, to have compassionate vows pervade our thoughts, and accomplish equal enlightenment (dengzhengjue 等正覺). Having great spiritual powers endowed with great compassion, how can we manifest [this compassion] to all categories of sentient beings who have fallen into [paths of rebirth as] denizens of hell, hungry ghosts, and beasts of

6 Liumen tuoluoni jing, T no. 1360, 21: 1.878a8-9. 
burden, as well among the humans and gods, who endure all manner of severe suffering and not set up skillful means to relieve them? We only desire to take pity [on these living beings] and liberate them from their tribulations.

世尊在昔, 為欲利樂諸有情故, 求證無上正等菩提. 悲願熏心, 成等 正覺. 有大神力, 具大慈悲. 何故現見, 諸有情類? 墮在地獄, 餓鬼 傍生, 及人天中, 受諸劇苦. 不設善巧, 方便濟拔. 惟願哀慗, 令脫 苦難. ${ }^{7}$

The dhäranī called 'Victory Banners and Arm Seals' (shengchuang biyin 勝幢臂印), which is said to be a 'wholesome method for relieving tribulations', is the solution to this problem. ${ }^{8}$ Thus, the idea that benefits and bliss for living beings can be brought to pass by relying on dhārañ pervades several of Xuanzang's translations. A few more examples will more fully flesh out Xuanzang's position on dhāranī being beneficial for all living beings. In the Sütra on the Heart of the Spirit Spell of the Eleven-Headed Avalokitesvara, the Bodhisattva Avalokiteśvara says:

I have a spirit spell heart (shenzhou xin 神呪心) called 'Eleven Headed', endowed with great majestic power, which has been preached by all eleven kotis of buddhas. I will now preach it because I desire to benefit and cause peace and bliss for all sentient beings, eliminate all illnesses, and eradicate all unwholesomeness, put a stop to all inauspiciousness, hold off all unwholesome dreams, and hinder all untimely deaths. I desire to cause the calming and purifying of all people with unwholesome minds, give peace and bliss to those who have anxieties and suffering, provide reconciliation for those who have adversaries (yuandui 怨對), eradicate all demonic hindrances, and accomplish all one mentally desires and seeks. O World-Honored One, I have not seen a god, or demon, or Brahmā, or śramaṇa, or brāhmana, and so forth, who protected his body by means of this

Sheng chuangbeiyin tuoluoni jing, T no. 1363, 21: 1.882c16-21.

8 Sheng chuangbeiyin tuoluoni jing, T no. 1363, 21: 1.882c25-26. 
spell, who preserved (shouchi 受持), verbally recited, copied, and distributed, who was able to be injured by any manner of calamities, demonic hindrances, swords and staves, poison, imprecations (yandao 厭禱), ${ }^{9}$ and spell techniques (zhoushu 呪術). By means of this spirit spell wherever one dwells, if boundaries have been made either near or far, I also do not see something being able to cross over and vex them, it only removes the response and ripening of determined unwholesome karma.

我有神呪心, 名 ‘十一面”，具大威力. 十一俱胝諸佛所說，我今說 之. 欲利益安樂一切有情、除一切病故, 滅一切惡故; 為止一切不吉 祥故; 為却一切惡夢想故; 為遮一切非時死故; 欲令諸惡心者得調 淨故; 有憂苦者得安樂故; 有怨對者得和解故; 魔鬼障礙皆消滅故; 心所願求皆稱遂故.世尊! 我不見世間，若天、若魔、若梵、若沙門、 若婆羅門等, 以此神呪, 防護其身. 受持讀誦, 書寫流布, 而為一切 災横、魔障、刀杖、毒藥、厭譸、呪術所能害者，我亦不見，以此神呪 隨所住處, 若遠若近, 結作界已. 有能越之, 來相嬈害, 唯除決定, 惡 業應熟. ${ }^{10}$

Thus, Avalokiteśvara preaches his dhārañī called 'Eleven Headed' because of his desire to provide benefits and bliss to all living beings. Xuanzang's translation emphasizes that the possession and preservation of the spell renders the one who chants it or carried it on his body invincible and unassailable to natural calamities, demonic infestations, weapons, poisons, curses, and unsolicited spells used against someone. In essence, the power of the dhärani $\bar{\imath}$ establishes a cordon of protection and prosperity around the person who preserves, chants, copies, and distributes it. The final passage of the sütra reiterates the purpose of this dhärañ $\bar{a}$ as promoting peace and bliss among living beings:

9 An imprecation is a kind of curse. Sometimes the compound yandao 厭 禱 is used to translate vetāla. Vetāla are ghost-like beings or spirits of Indian mythology who haunt or inhabit cadavers and charnel grounds. The vetāla has the power to make the cadaver move and it can enter or leave such a body at will. Here, however, I think 'imprecation' is more appropriate.

10 Shiyimian shenzhou xin jing, T no. 1071, 20: 1.152a24-b7. 
At this time the Bodhisattva-Mahāsattva Avalokiteśvara explained this sūtra, all in the great assembly simultaneously uttered praise: 'Well done! Well done, great beings. You have been able to desire benefits and peace and bliss for all sentient beings; hence, you have explained this spirit spell. We will follow it joyfully and also desire to receive and retain it'.

爾時觀自在菩薩摩訶薩說此經已, 一切大眾同時讚言, “善哉, 善哉, 大士! 乃能為欲利益安樂諸有情故, 說此神呪, 我等隨喜, 亦願受持’ ${ }^{11}$

In Xuanzang's translation of the Sütra on the Dhärañi for Maintaining the World (Chishi tuoluoni jing 持世陀羅尼經, $T$ no. 1162), the Buddha says that 'the power of the spirit spell [viz. dhärani] is inconceivable, for it will cause all sentient beings to obtain benefits and bliss' (此神呪力, 不可思議; 令諸有情, 皆獲利樂). ${ }^{12}$ Then, after the transliteration of the dhärañi, Xuanzang's translation further describes the beneficial and blissful matters associated with mastery of this dhārañi:

This dhārañi is endowed with great spiritual power. If good sons and good daughters preserve [this dhäranī and preach it for others with an utmost mind (sincere mind), all unwholesome ghosts, gods, dragons, yakșas, humans-yet-not-humans, and so forth, will not be able to harm [them]. All manner of beneficial and blissful matters will increase day and night. If they are able to make offerings to the three jewels with utmost sincerity and chant (niansong 念誦) this kind of dhārañ for the space of seven days and nights without any momentary lapses, all the gods, dragons, and spirits will rejoice, and the wealth and grain they need will appear by itself as unseen rain. Famines and plagues will all be eradicated, and the sinful hindrances people possess will be utterly annihilated. All that is dangerous and fear-invoking will be pacified, and blessing and wisdom will gradually increase, and that which is sought after will

11 Shiyimian shenzhou xin jing, T no. 1071, 20: 1.154c23-36.

12 Chishi tuoluoni jing, T no. 1162, 20: 1.667a8-9. 
be as one wishes. They will speedily realize unsurpassed, perfect enlightenment and bodhi.

此陀羅尼, 具大神力. 若有善男子、善女人, 至心受持, 廣為他說. 諸 惡神鬼、天龍、藥叉、人、非人等, 皆不能害. 諸利樂事, 書夜增長. 若 能至誠供養三寶, 念誦如是大陀羅尼, 經七書夜, 時無暫關. 諸天龍 神, 皆生歡喜. 自末冥雨所須財穀, 飢饉疫㾖, 皆悉消除. 所有罪障, 無不殁滅. 一切危懼, 並得安寧. 福慧漸增, 所求如意. 速證無上正 覺菩提. ${ }^{13}$

The translation then goes on to describe how if people preserve the dhärani, remember it, think about it, chant it, maintain it, and preach it widely to others, the benefits and bliss they seek will absolutely be brought to pass. ${ }^{14}$ The simple compound 'benefits and bliss' (lile 利樂) appears six times in the Sütra on the Dhäranī for Maintaining the World. There is nothing particularly special or unique about Xuanzang's use of this compound, however, because 'benefits and bliss' is a conventional stock phrase used in numerous sütras translated before and after Xuanzang's time, as well as in Mahāyāna and non-Mahāyāna Buddhist texts.

\section{Dhāraṇi and Disease Treatment}

In India and Central Asia, as well as China and East Asia, illness and disease were generally believed to be caused by all manner of spirits, demons, and creatures. ${ }^{15}$ Although some scholars seem to hold the opinion that the treatment of demon-induced disease is somehow Esoteric or Tantric, we must remember that the names of many of these sickness-causing spirits are also found in such mainstream

13 Chishi tuoluoni jing, T no. 1162, 20: 1.667a28-b6.

${ }_{14}$ Chishi tuoluoni jing, $T$ no. 1162, 20: 1.667b7-8: 爾時佛告妙月長者. 汝應 信受此陀羅尼. 憶念誦持廣為他說. 所求利樂無不諧遂.

15 See, for instance, Smith, The Self Possessed Deity; Strickmann, Chinese Magical Medicine. 
Mahāyāna sūtras as the Lotus Sūtra. These same illness-invoking imps also pervade Xuanzang's translations of dhäranī. In this section I will examine the efficacy of dhärani in treating disease. For instance, the Sütra on the Heart of the Spirit Spell of the Eleven-Headed Avalokiteśvara reports:

O World-Honored One, although these kinds of spirit spells are incomplete, they are yet able to bring about several kinds of undertakings. If one chants them with a sincere mind, he will absolutely obtain his desires. If one suffers from malaria, and suffers feverish fits once a day, once every two days, once every three days, or once every four days; or if one suffers from a ghost-induced illness, something caused by a pütana $\bar{a}^{16}$ something caused by a dākinini, ${ }^{17}$ something caused by a piśâca, ${ }^{18}$ something cause by a katapütana $\overline{,}{ }^{19}$ something caused by a madness-inducing ghost (diangui 癲鬼), something caused by an epilepsy-inducing ghost (xiangui 癎鬼), or something caused by all manner of other unwholesome ghosts, all of these, if one makes incantations over patients by means of this spell one hundred and eight times they will be able to be healed.

16 A pūtanā (buduogui 部多鬼), also transliterated as fuchagui 浮茶鬼 or fudanna 富單那, is translated into Chinese as a 'putrid hungry ghost' (xiu'egui 臭餓鬼). Among hungry ghosts, the pütanā is said to be the happiest and most prosperous. In Hinduism, Pūtanā (Putrefaction) is the name of a rākșasì (demoness) who is killed by the infant god Krishna. Pūtanā is also considered to be foster-mother of Krishna because she breast-fed him, although the demoness fed him with the purpose of killing him with poisoned milk. Thus, Pūtanā is usually described as an infantile disease or bird, symbolizing danger to infants and children-and it is even symbolic of a bad mother.

17 A däkini (chaqini 茶者尼, also written chazhini 茶枳尼) is a demon in the following of the goddess Kali who feeds on human flesh. They can be understood generally as vengeful female spirits, deities, imps, or fairies.

18 A piśāca (bishezhe 畢舍遮) is a meat-eating demon.

19 A kațapūtanā (jietuobudana 羊曷吒布怛那, also written jiazhafudanna 迦吒 富單那) is a kind of hungry ghost. It has been translated into Chinese as 'awful smelling ghost' (qixiugui 奇臭鬼) and 'extremely putrid ghost' (jixiugui 極臭鬼). 
世尊! 如是神呪, 雖不成立, 而亦能作種種事業. 至心念誦, 無不獲 願. 若患瘧病，或一日一發、或二日一發、或三日一發、或四日一發. 若患鬼病，或部多鬼所作、或茶耆(上聲呼)尼所作、或畢舍遮所作、 或羯吒(平聲呼)布怛那所作、或癲鬼所作、或㾞鬼所作、或餘種種惡 鬼所作、皆以此呪, 呪彼患者, 一百八遍, 即得除愈. ${ }^{20}$

Xuanzang's translation asserts that this dhärañ will efficaciously treat all manner of illnesses and discomforts induced by a wide variety of spirits, ghosts, and demons. Malaria, madness, and epilepsy are the only illnesses referred to by name, but Xuanzang's translation asserts that any illness caused by a pütanā, dākini, piśāca, kațaputan $\bar{a}$, and other spirit beings will be cured by the dhārañi. What is also significant is that any practitioner, and so one assumes that this includes laymen and laywomen, can invoke the power of the $d \bar{a}$ rañi to cure illness and disease by following the simple procedure described by Xuanzang in the sütra.

In his translation of the Sütra on the Heart of the Spirit Spell of the Eleven-Headed Avalokiteśvara, Xuanzang articulates how to make an eleven-faced or eleven-headed image of Avalokiteśvara and various ritual practices associated with it to accomplish various purposes. Some of the faces are wrathful and some compassionate. Some of the dhärañi presented in the siutra are used to empower substances, such as spell-knots and threads, that are tied on different faces of the image, burned in front of the image, and so forth. One such image ritual describes the use of five-colored thread to make spell-knots to get control of an illness afflicting an individual:

If one with serious hindrances uses a five-colored thread, intones the spell, and makes a knot, one time [chanting the spell] per one knot, and all together makes one hundred and eight knots, and he fastens them on the sick person's neck or fastens them on his arms, his sinful hindrances will be eradicated, his illnesses will immediately be healed. If one suffers from boils, tumors, ulcerous skin sores, smallpox, gangrenous ulcers, and so forth, all manner of unwholesome

20 Shiyimian shenzhou xin jing, T no. 1071, 20: 1.153c13-19. 
illnesses, or if one is injured by a blade, an arrow, a lance, or so forth, or if one is stung by a snake, scorpion, centipede, poisonous wasp, or so forth, all of these, if one incants this spell seven times, they will be able to be healed. If one has serious hindrances, enchant yellow earthen clay seventeen times, apply it to the sores, and his suffering will be healed. If one's skin becomes inflamed, or one suffers from paralysis, blindness, deafness, a chronically stuffy nose, or dimwittedness, he should chant this spell with a sincere mind and if he incants it over a patient one hundred and eight times, the illness will immediately be healed. If one with serious hindrances lightly fries birch tree bark and laurel tree incense in oil or butter, and throughout the process incants [the spell] seven times, and then applies it to his body or drips it into his ears or nose, or causes it to be swallowed, that which he suffers from then be healed. If one suffers from all manner of other illnesses, all of them should be treated by chanting this spell over it with a sincere mind, or one should chant by oneself and one will be healed immediately.

若障重者, 用五色縷, 誦呪作結. 一遍一結, 凡一百八結. 以繫病人 頸上, 或繫臂上, 罪障消滅, 病即除愈. 若患丁腫、癱腫、瘻瘡、疮瘕、

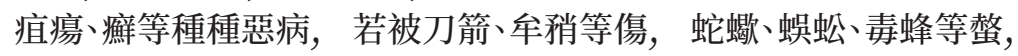
皆以此呪，呪之七遍，即得除愈. 若障重者，呪黄土埿至一七遍. 用 塗病處, 所苦得除愈. 若患緩風、偏朋風、耳聾、鼻塞、㿂風等病, 皆應 至心念誦此呪. 呪彼患者一百八遍, 病即除愈. 若障重者, 以油或酥, 煎樺皮及青木香, 每呪七遍, 即用塗身, 或滴耳鼻. 或令服之, 所患 便愈. 若有所餘種種疾病, 皆應至心, 以此呪之. 或自念誦, 即得除 差. ${ }^{21}$

One scholar asserts that Xuanzang's translation of the Sütra on the Heart of the Spirit Spell of the Eleven-headed Avalokitesvara, being the shortest of the extant translations, is the most basic recension of the dhäranī on the eleven-headed Avalokiteśvara. Being primarily concerned with healing, he asserts it contains only mantras and suggests that it either represents a variant or an earlier version of the

21 Shiyimian shenzhou xin jing, T no. 1071, 20: 1.153c19-154a2. 
dhārañ than Yaśogupta's translation, which was translated in the mid-sixth century (between 564 and 572). ${ }^{22}$ Other scholars more fruitfully recognize that Xuanzang's translations corresponds to the first roll (juan 卷) of Amoghavajra's translation of the Shiyimian Guanzizai pusa xinmiyan niansong yigui jing 十一面觀自在菩薩 心密言念誦儀軌經 (Ritual Manual Sūtra on the Recitation of the Heart-Mantra of the Eleven-headed Bodhisattva Avalokiteśvara, $T$ no. 1069), but they do not emphasize that it includes basic procedures for fire rituals. ${ }^{23}$ In his translation of the Sütra on the Heart of the Spirit Spell of the Eleven-Headed Avalokitesvara, Xuanzang articulates three elementary fire rituals (Skt. homa; Ch. bumo; Jp. goma 護摩). These fire rituals, not called boma in the text, are presented in the context of rituals associated with an eleven-headed image made by the practitioner and used for various purposes. Let us briefly examine the procedures of the three fire rituals:

Furthermore, if people or beasts within the country are afflicted with an epidemic, [a practitioner should] burn zhupo wood ${ }^{24}$ in front of this image. Again, he specifically selects that wood and cuts it into a thousand and eight inch-length segments, applies mustard seed oil to each and every segment, enchants them one time [each], and casts them into the fire until they are all consumed. And again, [if] he selects a dark red threat and makes seven spell-knots, binding one spell

22 See Sørensen, 'Introduction', esp. 98.

23 Abé, The Weaving of Mantra, 167; Shinohara, Spells, Images, and Mandalas, 16. Abé recognizes the existence of fire rituals, but does not emphasize them; but Shinohara glosses over its existence. Granted, Abé's purpose in discussing the text is to problematize the concept of 'mixed esoteric Buddhism' by advancing a theory that dhārañ $\bar{i}$ texts that function primarily as ritual manuals is a better way to differentiate 'exoteric' and 'esoteric' dhārañī. See Abé, The Weaving of Mantra, 167-68. However, because all of Xuanzang's translations are simple ritual texts, strict adherence to this theory must be used as evidence that Xuanzang was an 'esoteric' monk.

${ }^{24}$ Zhupo wood (zhupomu 住婆木) is elsewhere written renpomu 任婆木; but what it refers to is not known. 
per one knot, and places them on the crown of the highest Buddha head, he will be able to cause the epidemic to be eradicated and once the epidemic is eliminated, loose a spell-cord.

復次, 若國土中, 人畜疫起, 於此像前, 然住婆木火. 復別取彼木, 寸 截以為一千八段, 每取一段, 塗芥子油. 呪之一遍, 擲置火中, 乃至 皆盡. 復取緋縷, 作七呪結. 一呪一結, 繫置最上佛面頂上. 能令疫 病, 一切消除. 疾疫除已, 解去呪索. 25

The brief procedures described concisely by Xuanzang are a standard procedure for a fire ritual. The wood cut into 1,008 segments or pieces seems to be amplification of the 108 defilements-the underlying cause of the epidemic or illness-which are symbolically burned away or eradicated through the ritual. Mustard seed oil is commonly used in Hindu and Jain fire rituals, as well. ${ }^{26}$ After the figurative cleansing of the individual's hindrances through the fire ritual, the spell-knot empowered by means of the dhärani $\bar{\imath}$ bind the epidemic to Avalokiteśvara. Here, Xuanzang clearly draws upon one of the standard definitions and explanations of the efficacy of dhärañ $\bar{\imath}$ that was also known to Xuanzang's contemporary, the monk-encyclopedist Daoshi 道世 (ca. 596-683). In the first of two chapters on 'Spell Techniques' (zhoushu 呪術) in his influential and imperially-sponsored, A Grove of Pearls in the Garden of the Dharma (Fayuan zhulin 法苑珠林), Daoshi describes the power of dhārañ $\bar{\imath}$ to bind and hold as follows:

Dhārañi (tuoluoni 陀羅尼) are the sounds of the Brahmā heaven of the West and, translated [into the language of] the Chinese people of the East, they are called $c h i$ 持 (to hold, to support). They are chanted to hold on to what is wholesome (shan 善) and not lose it and to hold on to what is unwholesome ( $e$ 惡) so it will not be produced. According to the words [of the spell], which are spoken, you may rule completely over all transformations. If you administer

26 Cort, Jains in the World, 165-66. 
the performance in accordance with [its prescribed] methods ( $f a$ 法), merit and effects will be experienced immediately. [Hence, you will be able] to smash rocks or pluck out trees, remove illness and eradicate disease. Suffering is removed following the pronunciation of the sounds, and things happen right when the tones flutter in the wind.

然“陀羅尼” 者, 西梵天音; 東華人譯, 則云 ‘持”也: 明 “持善不失, 持 惡不生’ 據斯以言, 彌綸一化, 依法施行, 功用立驗. 或碎石拔木, 或移痛滅痾, 隨聲發而苦除, 逐音颺而事舉. 27

The second elementary fire ritual described by Xuanzang in this translation is specifically for an individual who is not getting better from a chronic illness.

Furthermore, if one is ill for a long time and does not seem to be getting better, or if unwholesome ghosts come into his house, he should select a hundred and eight grains of kunduruka incense, ${ }^{28}$ and before this image enchant each grain one time and casts them into the fire until they are all consumed. And again, one selects a white thread and makes twenty-one spell-knots, [chanting] one spell per one knot, binds it on the crown of the compassionate face just as before, and after one night loosen it. If it is bound to the neck of an afflicted person, he will be cured of his affliction and the evil spirits (unwholesome ghosts) will be dispersed.

復次, 若有長病, 困苦不差. 或惡神鬼, 來入宅中, 應取薰陸香一百 八顆, 在此像前顆呪一遍. 擲置火中, 乃至皆盡. 復取白縷, 作二十 一呪結. 一呪一結, 繫置當前慈悲面頂上, 經一宿已解取. 以繫病者 頸上, 所患除愈, 惡鬼退散. ${ }^{29}$

27 Fayuan zhulin, T no. 2122, 53: 60.734c22-26.

28 Kunduruka incense (xunluxiang 薰陸香) is made from the resin of the plant Boswellia thurifera, an aromatic tree.

29 Shiyimian shenzhou xin jing, T no. 1071, 20: 1.154c1-6. 
This dhärañ is chanted over 108 grains of incense, which, as before, is symbolic of the 108 defilements. As before, these enchanted and empowered grains of incense are cast into fire, and then to make doubly sure of the success of the ritual, a spell-knot is bound to the compassionate face of image of Avalokiteśvara made by the practitioner of this text; a spell-knot is also bound to the neck of the afflicted. What is significant here is that anyone is able to perform this ritual. No restrictions are described in the text; although it is likely that monks were among the more frequent performers. The third fire ritual responds specifically to the possibility that somebody has been imprecated, or cursed, by another person.

Furthermore, if an enemy seeks an occasion to dispute with or imprecate you, and seeks to harm you, you should take all manner of incense and flowers, present them as offerings to this image, and burn a varrsika tree ${ }^{30}$ before the image. [A practitioner] selects one hundred and eight seeds of the rape plant, chants [the spell] one time each [over each seed] and casts them into the fire. And again, he selects a white thread and ties one hundred and eight knots, [chanting] one spell per one knot. Binding [the knots] on the crown of the wrathful face on the right side of this image, after one night has passed, he loosens this cord, invokes the name of his enemy, and cuts the knots one by one, and casts them to a different place. If he makes one invocation per one cut until they are all exhausted, he will cause his enemy to not achieve his works and naturally/spontaneously submit to him.

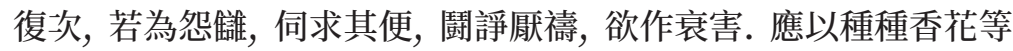
物, 供養此像. 以婆銆迦木, 像前然火. 取芸臺子一百八顆, 各呪一 遍, 擲置火中. 復取白縷結作一百八結. 一呪一結, 繫著此像左邊瞋 面頂上. 經一宿已, 解取此索. 稱怨倠名名, 截一一結, 各令異處. 一稱 一截, 乃至都盡. 今彼怨倠, 所作不遂, 自然歸伏. ${ }^{31}$

30 Vārșika tree (poshuojiamu 婆鏫迦木) refers to a flower that blooms in the rainy season.

31 Shiyimian shenzhou xin jing, T no. 1071, 20: 1.154c7-13. 
As above, the practitioner selects 108 seeds of the rape plant and enchants them with the sutra. Rape plant seeds are also a commonly used object in the fire rituals. As before, the 108 seeds are figurative of the 108 defilements commonly referred to in all Buddhist literature. The practitioner makes 108 spell-knots, which also seem to be symbolic of the defilements, and these are bound one at a time to wrathful faces of the image. As before, the power of the dhärani binds the curses cast on the practitioner to the wrathful personification of Avalokiteśvara, and as they are cut and dispersed in different places, the dhārani dissipates the power of the imprecation away from the practitioner. Thus, Xuanzang understands the efficacy of $d \bar{a}$ ranni $\bar{\imath}$ to be closely intertwined with the basic function of dhärani $\bar{\imath}$ to grasp, hold, or bind unwholesomeness so that the unwholesome thing (imprecation, curse, counter spell, injury) will not be produced and can be disposed of safely.

\section{Dhārañi and the Bodhisattva Path}

The final important theme in Xuanzang's translations of dhäranī is the assertation that certain $d \bar{b} \bar{r}$ ran $\bar{\imath}$ are conducive to practice and fruitful advancement on the bodhisattva path. The Sütra on the Dhärani for Relieving Tribulations (Baji kunan tuoluoni jing 拔濟 苦難陀羅尼經) prescribes the practice of preserving (shouchi) the dhārañi as being beneficial for making what Buddhists would typically describe as 'seminal progress' (jingjin 精進) on the path toward Buddhahood.

If there are good sons and good daughters who with utmost sincerity respectfully worship the Tathāgata Destroyer of the Unwholesome Destinies, Arhat, and Samyak-sambuddha and preserve this spell, for fourteen thousand kalpas they will constantly remember their past lives, wherever they will obtain a man's body, they will be fully endowed with all senses, and they will have deep faith in cause and effect. They will be good at [religious] techniques and have a sublime understanding of all treatises. They will like practicing giving and forsake all the passions. They will not create unwholesome karma 
and abandon all perilous fear. They will be endowed with correct life wisdom and be loved and respected by the masses. They will always be close to spiritual mentors and constantly hear the true dharma. They will seek the bodhicitta (putixin 菩提心) and will never even momentarily forsake it. They will adorn themselves with all the meritorious virtues, be endowed with wholesome vinaya and decorum, and fear all unwholesome karma. They will always be devoid of deficiencies [in means] and be harmonious, flexible, blissful, and calm. They will always receive joy and bliss when among gods and humans. They will quickly realize unsurpassed, perfect bodhi. At the end of their lives, they will not regress in [their practice] of the ten perfections (shi daobian 十到彼岸). They will always desire benefits and bliss for all sentient beings, and all that they have cultivated and practiced will not solely be for their own personal benefit. Wherever they are reborn they will always be able to see the Buddha, they will protect and maintain the true dharma, and have a place for themselves in the throngs of the worthies and saints.

若有善男子、善女人，至誠禮敬滅惡趣王如來應正等覺，受持此呪， 萬四千劫, 常憶宿命. 所在生處, 得丈夫身. 具足諸根, 深信因果. 善 諸技術, 妙解諸論. 好行惠施, 厭捨諸欲. 不造惡業, 離諸危怖. 具正 命慧, 眾所愛重. 常近善友, 恒聞正法. 求菩提心, 曾無暫捨. 以諸功 德, 而自莊嚴. 具善律儀, 怖諸惡業. 恒無實乏, 調柔樂靜. 於天人 中，常受快樂，速證無上正等菩提，終不退於十到彼岸. 常願利樂， 一切有情. 諸所修行, 非專自利. 在所生處, 常得見佛. 護持正法, 預 賢聖眾. ${ }^{32}$

This dhärañi promises that if someone 'preserves' it, he or she will possess all the qualities of a bodhisattva who is making seminal progress on the path toward Buddhahood. All the spiritual benefits of preserving (and chanting) this dhärani $\bar{\imath}$ are the conventional promises found in many mainstream Mahāyāna sütras: always receive a male body, always be able to find spiritual mentors, not regress on the bodhisattva path, practice for the benefit of self

32 Baji kunan tuoluoni jing, T no. 1395, 21: 1.912c15-25. 
and others, not regress in the practice of the ten perfections, and so forth.

The Sütra on the Dhārani of the Heart of All Buddhas (Zhufoxin tuoluoni jing 諸佛心陀羅尼經, $T$ no. 918) contains similar promises of progression on the bodhisattva path for one who recites the dhärani $\overline{\text { : }}$

If one has an utmost mind, preserves and verbally recites [this dhäranī $]$, he will transcend the severe suffering of birth and death for hundreds of thousands of kalpas, he will be absorbed in the bodhi of unsurpassed perfect enlightenment, and he will be able to quickly cultivate eternal non-retrogression until he attains the bodhi of unsurpassed perfect enlightenment. He will never be born in vain in a world system without buddhas, and he will always comprehend all dhäranīis well. He will constantly see Tathāgatas, be in close proximity and make offerings to them. He will always remember his previous lives and deeply believe in [karmic] cause and effect. He will be able to cause the offenses of humans, non-humans, and so forth, in the present-world to be completely eradicated. Sickness and injury will not attack one, and one will not die young. The affairs of all unwholesome demons will all be utterly annihilated. All the unwholesome karma one possesses will be eradicated, and all the demonic forces will be surprised and scatter.

若有至心, 受持讀誦. 超百千劫, 生死劇苦. 定於無上, 正等菩提. 能 速修行, 永無退轉, 乃至無上正等菩提. 終不枉生無佛世界. 恒善悟 解諸陀羅尼. 常見如來, 親近供養. 恒憶宿命, 深信因果. 能使現世 人非人等, 怨害皆除. 疾病不侵, 無有中夭. 諸惡魔事, 皆悉殄滅. 所 有惡業, 無不消除. 一切魔軍, 驚怖退散. 33

The only procedure one must follow to receive these significant spiritual blessings of always being born in times and places where buddhas are present-always being able to make offerings to buddhas, attaining non-retrogression on the bodhisattva path, being able to expurgate all the offenses of living beings, being immune to sickness

33 Zhufoxin tuoluonijing, T no. 918, 19: 1.1a14-21. 
and illness avoiding death as a child, and able to disperse the forces of evil-is to preserve and recite the dhäranì .

Xuanzang's most famous dhärani translation, the Sütra on the Six Approach Dhärani in Six Approaches (Liumen tuoluoni jing 六 門陀羅尼經, $T$ no. 1360), however, is instructive because of Xuanzang's diction. The 'procedure' or 'method' ( $f a$ 法) one must receive (shou 受) to draw on the power of this dhärani is to make six vows that resonate with standard bodhisattva vows. If one holds the well-established position that Xuanzang was a representative of normative Mahāyāna Buddhist doctrine and its concomitant ritual, one can easily understand why Xuanzang would be drawn to this dhārañì:

At that time, the World-Honored One addressed all the bodhisattvas, 'O good sons, if you desire to benefit and give peace and bliss to living beings, you should receive the procedure of this dhärañ in six approaches and say, [1] 'I will transmigrate in the cycle of rebirth and death, receive all manner of suffering, and never cause living beings to receive these same sufferings. [2] All the riches, honor, and worldly bliss one can receive, I vow that all living beings will receive this same bliss. [3] Regarding unwholesome [acts] I have committed, if I have not yet repented of them, in the end I will not utter the unsurpassed dharma. [4] Regarding all the masses of demonic karma I possess, if I do not at first awaken, in the end I will not raise the thought and lay hold of the unsurpassed dharma. [5] Regarding päramitās I possess [that] which I have embraced, extensive wholesome roots in all mundane and transmundane [realms], I vow that all living beings will speedily realize the fruit [fruition reward] of unsurpassed knowledge. [6] Regarding the liberation I have realized, I also vow that living beings will all obtain liberation and will never allow [living beings] to abide in attachments [or to be attached] in samsāra and nirvāna'.

爾時, 世尊告諸菩薩，‘善男子! 若欲利益, 安樂眾生, 汝當受此六門 陀羅尼法. 謂我流轉於生死中, 諸所受苦. 勿令眾生, 同受斯苦. 諸 有所受, 富貴世樂. 願諸眾生, 同受斯樂. 我所作惡, 若未先悔, 終不 發言, 稱無上法. 我諸所有眾魔之業, 若未先覺, 終不舉心, 緣無上 
法. 我諸所有, 波羅蜜多所攝. 一切世及出世, 廣大善根, 願諸眾生, 皆當速證無上智果. 我證解脫, 亦願眾生, 皆得解脫. 勿令住著, 生 死涅槃” ${ }^{34}$

Each of these six approaches or vows is a common bodhisattva vow: to stay in the cycle of rebirth and death to liberate all living beings; to help all living beings achieve bliss and happiness in this life; to repent of one's unwholesomeness and not preach the dharma if one does not repent; to vow to arouse the bodbicitta; to vow to help all living beings achieve the fruits of the bodhisattva's perfections; and to vow to not attain liberation until all living beings are liberated from the cycle of rebirth and death. Considering that Xuanzang held the position that there were icchantikas (wuming 無明), living beings who were unable to attain enlightenment because they were troubled by and mired in various kinds of mental defilements, we may conjecture that passages such as this and the preceding quotation may have served to provide hope to Xuanzang that dark mental forces that keep living beings in ignorance could be held at bay by the power of dhärañi. Also note that providing benefits and peace and bliss is emphasized significantly in this passage.

\section{Conclusion}

The preface to Xuanzang's biography, Life of the Dharma Master Sanzang of Da Ci'en Monastery of the Great Tang dynasty (Da Tang Da Ci'en si sanzang fashi zhuan 大唐大慈恩寺三藏法師傳), compiled by his disciple Yancong, emphasizes that dhārañi, literally 'spell techniques' or 'spellcraft' (zhoushu 呪術), along with the practice of meditation and the observance of monastic discipline, is but one of the myriads of mainstream Buddhist ways leading to the one goal of dispelling illusion and benefiting living beings. ${ }^{35} \mathrm{~A}$ direct examination of the dhârañ sütras translated by Xuanzang supports this

\footnotetext{
34 Liumen tuoluoni jing, T no. 1360, 21: 1.878a8-16.

35 Da Tang Da Ci'en si sanzang fashi zhuan, T no. 2053, 50: 1.220c.
} 
assertion. As we have observed above, the position that dhārañi benefit and cause bliss for ordinary living beings is a theme that pervades Xuanzang's translations. These benefits are described as both temporal and spiritual, eminently mundane as well as transcendent. The efficacy of $d \bar{a} \bar{r}$ ran $\bar{i}$ in the elimination of illnesses caused by and used for protection from the gamut of ghosts, spirits, goblins, and demons that were believed to inhabit the mundane world also permeates Xuanzang's translations. Because most of Xuanzang's translations are very short texts, the procedures concomitantly are simple in their construction. Yet, Xuanzang's translation of the Sütra on the Heart of the Spirit Spell of the Eleven-Headed Avalokitesvara shows that he was familiar with dhärañ $\bar{i}$ procedures used in empowering images and using those images in rituals to eliminate illnesses and other mal-

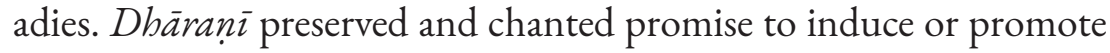
seminal progress on the bodhisattva path were also extremely important to Xuanzang. Xuanzang's disciples, as exemplified by Yancong, understood $d \bar{a} \bar{r}$ rañ $\bar{\imath}$ as one of the three primary ways of overcoming the delusions of the world and providing benefit to living beings.

Xuanzang epitomizes the quintessential conventional or mainstream Mahāyāna monk in East Asia. However, all eight of Xuanzang's translations of dhārañi are simple ritual texts. Xuanzang's translations of dhärani clearly demonstrate that ritual activity, or

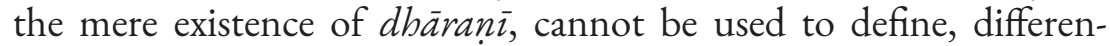
tiate, or postulate the existence of 'esoteric Buddhism', without severe qualifications. For instance, none of Xuanzang's translations describe dhäranī in rituals of initiation or consecration, which I, in agreement with Gregory Schopen, assert is a significant component of a truly functional definition of 'esoteric' or 'tantric' Buddhism. ${ }^{36}$

36 Gregory Schopen, for instance, asserts that most dhārañ $\bar{\imath}$ are not Tantric: 'if by "Tantric" we mean that phase of Buddhist doctrinal development which is characterized by an emphasis on the central function of the guru as religious preceptor; by sets-usually graded - of specific initiations; by esotericism of doctrine, language and organization; and by a strong emphasis on the realization of the goal through highly structured ritual and meditative techniques. If "Tantric" is to be used to refer to something other than this, then the term must be clearly 


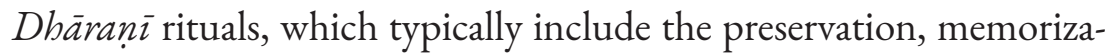
tion, chanting, or wearing on the body of $d \bar{a} \bar{r} a n \bar{i}$, or even the use of $d h \bar{a}$ rañ $\bar{\imath}$ to empower images, which are then used in more detailed rituals, are mainstream Mahāyāna Buddhism. In Xuanzang's view,

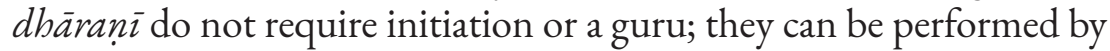
monks and lay people, and the texts themselves encourage widespread use by all manner of living beings. If Xuanzang did not think that $d \bar{a}$ rañ $\bar{\imath}$ were functional and efficacious for all living beings, what was he doing translating them? One would have to assert that Xuanzang translated them without knowing what they really were or how they functioned. Such a position is absurd because few Chinese monks spent the amount of time in India and Central Asia that Xuanzang did. Xuanzang spoke the language and knew what authentic Indian Buddhism was in his time more than any other Chinese monk.

Other relevant questions can only be answered with speculation: What was the source of Xuanzang's dhäranī texts? Was Xuanzang drawn to these texts because they were prevalent in India or Central Asia? These questions cannot be answered in a satisfactory manner, but raising them must force us to accept the possibility that dhârañ and the rituals for their use were indicative of mainstream Mahāyāna Buddhism in India and Central Asia. Furthermore, Xuanzang was only able to translate seventy-six of the more than six hundred sütras he brought home to China. That nine of these seventy-six were dhārañi strongly suggests that dhärañi held a significant place in Xuanzang's personal Buddhist practice and devotions. The simple and effective Mahāyāna ritual associated with dhārañi sütras should not be mistaken for a separate system. Xuanzang is the poster boy of mainstream Mahāyāna Buddhism, and his interest in and understanding of dhärañ must be viewed as evidence for their functionality and widespread popularity in conventional medieval East Asian Buddhism.

defined and its boundaries must be clearly drawn. Otherwise the term is meaningless and quite certainly misleading'. See Schopen, 'The Text of the "Dhāranī Stones from Abhayagiriya”, esp. 105; see also Schopen, 'Bodhigarbhālañkāralakṣa and Vimaloṣnịịa Dhāraṇīs in Indian Inscriptions’, esp. 147. 


\section{Appendix}

\section{Table 1: Classifications of Dhärañi in East Asian Exegesis}

\begin{tabular}{|c|c|c|c|c|}
\hline Text Name & 1 & 2 & 3 & 4 \\
\hline $\begin{array}{l}\text { Sanskrit } \\
\text { Yogācārabbūmi }\end{array}$ & $\begin{array}{l}\text { dharma- } \\
\text { dhāraṇi }\end{array}$ & artha-dhāraṇi & $\begin{array}{l}\text { mantra- } \\
\text { dhāraṇi }\end{array}$ & $\begin{array}{l}\text { bodhisattva- } \\
\text { kșāmti- } \\
\text { labhāyaca } \\
\text { dhārañi }\end{array}$ \\
\hline $\begin{array}{l}\text { Da zhidu lun } \\
\text { 大智度論 } \\
\text { (Tno. 1509, 25: } \\
28.268 \mathrm{a}-\mathrm{b}) \\
\text { trans. ca. } \\
402-406 \text { by } \\
\text { Kumārajīva }\end{array}$ & $\begin{array}{l}\text { fenbie zhufa } \\
\text { tuoluoni } \\
\text { 分別諸法陀 } \\
\text { 羅尼 } \\
\text { (dhārañ for } \\
\text { discriminating } \\
\text { all dharmas) }\end{array}$ & $\begin{array}{l}\text { wenchi tuolinni } \\
\text { 聞持陀鄰尼 } \\
\text { (dhāran̄i } \\
\text { for the } \\
\text { maintenance } \\
\text { of what one } \\
\text { has heard) }\end{array}$ & $\begin{array}{l}\text { ruyinsheng } \\
\text { tuoluoni } \\
\text { 入音聲陀羅尼 } \\
\text { (dhāran̄i } \\
\text { entering into } \\
\text { sounds) }\end{array}$ & $\begin{array}{l}\text { zirumen } \\
\text { tuoluoni } \\
\text { 字入門陀羅尼 } \\
\text { (dhāranni that } \\
\text { penetrate } \\
\text { letters/ } \\
\text { phonemes) }\end{array}$ \\
\hline $\begin{array}{l}\text { Pusa dichi jing } \\
\text { 菩薩地持經 } \\
\text { (Tno. } 1581,30 \text { : } \\
8.934 a-b) \\
\text { trans. ca. } \\
\text { 414-421 by } \\
\text { Dharmakṣema }\end{array}$ & $\begin{array}{l}\text { fa tuoluoni } \\
\text { 法陀羅尼 } \\
\text { (dharma } \\
\text { dhāranī })\end{array}$ & $\begin{array}{l}\text { yi tuoluoni } \\
\text { 義陀羅尼 } \\
\text { (meaning } \\
\text { dhārañi) }\end{array}$ & $\begin{array}{l}\text { zhoushu } \\
\text { tuoluoni } \\
\text { 哠術陀羅尼 } \\
\text { (spell- } \\
\text { technique } \\
\text { dhārañin) }\end{array}$ & $\begin{array}{l}\text { ren tuoluoni } \\
\text { 忍陀羅尼 } \\
\text { (acquiescence } \\
\text { dhāraṇi) }\end{array}$ \\
\hline $\begin{array}{l}\text { Shidijing lun } \\
\text { 十地經論 } \\
\text { (Tno. 1522, 26: } \\
11.191 \mathrm{c}-192 \mathrm{c}) \\
\text { trans. ca. } 508 \\
\text { by Bodhiruci }\end{array}$ & $\begin{array}{l}\text { fa tuoluonil } \\
\text { fachi } \\
\text { 法陀羅尼/法持 } \\
\text { (dharma } \\
\text { dhāranī; } \\
\text { dharma } \\
\text { maintenance) }\end{array}$ & $\begin{array}{l}\text { yi tuoluoni/ } \\
\text { yichi } \\
\text { 義陀羅尼/義持 } \\
\text { (meaning } \\
\text { dhāranī; } \\
\text { meaning } \\
\text { maintenance) }\end{array}$ & $\begin{array}{l}\text { zhoushu } \\
\text { tuoluoni } \\
\text { 呪術陀羅尼 } \\
\text { (spell- } \\
\text { technique } \\
\text { dhārañī) }\end{array}$ & $\begin{array}{l}\text { ren tuoluonil } \\
\text { renchi } \\
\text { 忍陀羅尼/忍持 } \\
\text { (acquiescence } \\
\text { dhāranīi } \\
\text { acquiescence } \\
\text { maintenance) }\end{array}$ \\
\hline $\begin{array}{l}\text { Dasheng yizhang } \\
\text { 大乘義章 } \\
\text { ( T no. 1851, 44: } \\
11.685 \text { a-686a) } \\
\text { composed ca. } \\
592 \text { by Jingying } \\
\text { Huiyuan }\end{array}$ & $\begin{array}{l}\text { fa tuoluonil } \\
\text { fachi } \\
\text { 法陀羅尼/法持 } \\
\text { (dharma } \\
\text { dhāranī; } \\
\text { dharma } \\
\text { maintenance) }\end{array}$ & $\begin{array}{l}\text { yi tuoluoni/ } \\
\text { yichi } \\
\text { 義陀羅尼/義持 } \\
\text { (meaning } \\
\text { dhāranī; } \\
\text { meaning } \\
\text { maintenance) }\end{array}$ & $\begin{array}{l}\text { zhoushu } \\
\text { tuoluoni } \\
\text { 呪術陀羅尼 } \\
\text { (spell- } \\
\text { technique } \\
\text { dhārañī) }\end{array}$ & $\begin{array}{l}\text { ren tuoluonil } \\
\text { renchi } \\
\text { 忍陀羅尼/忍持 } \\
\text { (acquiescence } \\
\text { dhārañī; } \\
\text { acquiescence } \\
\text { maintenance) }\end{array}$ \\
\hline
\end{tabular}


342 RICHARD D. MCBRIDE II

\begin{tabular}{|c|c|c|c|c|}
\hline Text Name & 1 & 2 & 3 & 4 \\
\hline $\begin{array}{l}\text { Yuqie shidilun } \\
\text { 瑜伽十地論 } \\
\text { (Tno. 1579, 30: } \\
45.542 \mathrm{c}-543 \mathrm{~b}) \\
\text { trans. ca. } \\
\text { 646-648 by } \\
\text { Xuanzang }\end{array}$ & $\begin{array}{l}\text { fa tuoluoni } \\
\text { 法陀羅尼 } \\
\text { (dharma } \\
\text { dhārañi) }\end{array}$ & $\begin{array}{l}\text { yi tuoluoni } \\
\text { 義陀羅尼 } \\
\text { (meaning } \\
\text { dhārañi) }\end{array}$ & $\begin{array}{l}\text { zhou tuoluoni } \\
\text { 呪陀羅尼 } \\
\text { (spell-dhāranī) }\end{array}$ & $\begin{array}{l}\text { ren tuoluoni } \\
\text { 忍陀羅尼 } \\
\text { (acquiescence } \\
\text { dhārañi) }\end{array}$ \\
\hline $\begin{array}{l}\text { Zongshi tuoluoni } \\
\text { yizan } \\
\text { 總釋陀羅尼義讚 } \\
\text { (T no. 902, 18: } \\
\text { 1.898a-b) } \\
\text { apocryphal text } \\
\text { attributed to } \\
\text { Amoghavajra }\end{array}$ & $\begin{array}{l}\text { fachi } \\
\text { 法持 } \\
\text { (dharma } \\
\text { maintenance) }\end{array}$ & $\begin{array}{l}\text { yichi } \\
\text { 義持 } \\
\text { (meaning } \\
\text { maintenance) }\end{array}$ & $\begin{array}{l}\text { sanmodichi } \\
\text { 三摩地持 } \\
\text { (samādhi } \\
\text { maintenance) }\end{array}$ & $\begin{array}{l}\text { wenchi } \\
\text { 文持 } \\
\text { (word or } \\
\text { pattern } \\
\text { maintenance) }\end{array}$ \\
\hline
\end{tabular}




\section{Bibliography}

Abbreviations

Taishō shinshū daizōkyō大正新脩大蔵経. See Bibliography, Secondary Sources, Takakusu and Watanabe, eds.

\section{Primary Sources}

Baji kunan tuoluoni jing 拔濟苦難陀羅尼經 [Sūtra on the Dhāraṇi for Relieving Tribulations], T no. 1395, vol. 21.1 juan.

Translated by Xuanzang 玄牀 (602-664), ca. 654 .

Baming pumi tuoluoni jing 八名普密陀羅尼經 [Sūtra on the Dhāraṇī of the Universal Esoterica of the Eight Names], T no. 1365, vol.

21. 1 juan. Translated by Xuanzang 玄牀 (602-664), ca. 654.

Bore boluomiduo xin jing 般若波羅蜜多心經 [Skt.

Prajñāpāramitāhrdaya-sütra; Heart Sütra], T no. 251, vol. 8. 1

juan. Translated by Xuanzang 玄牀 (602-664), ca. 649.

Bukong juansuo shenzhou xin jing 不空罥索神咒心經 [Skt.

*Amoghapāsahrdaya; Sūtra on the Heart of the Spirit Spell of Amoghapāśa], Tno. 1094, vol. 20. 1 juan. Translated by Xuanzang 玄牀 (602-664) on May 15, 659, at Da Ci'en si Monastery 大慈恩寺.

Chishi tuoluoni jing 持世陀羅尼經 [Sūtra on the Dhāraṇī for

Maintaining the World; Skt. Vasudhāra-dhārañi], T no. 1162, vol. 20. 1 juan. Translated by Xuanzang 玄牀 (602-664), ca. 654.

Da Tang Da Ci'en si sanzang fashi zhuan 大唐大慈恩寺三藏法師傳

[Life of the Dharma Master Sanzang of Da Ci'en si Monastery of the Great Tang dynasty], T no. 2053, vol. 50. 10 juan. By Yancong 彥悰 (d.u.), ca. seventh century.

Dasheng yizhang 大乘義章 [Mahāyāna Compendium], T no. 1851, vol. 44. 20 juan. By Jingying Huiyuan 淨影慧遠 (523-592).

Dazhidu lun 大智度論 [Treatise on the Great Perfection of Wisdom], T no. 1509, vol. 25. 100 juan. Attributed to Nāgārjuna (Longshu 龍樹, ca. 150-200). Translated by Kumārajīva (Jiumoluoshi 鳩摩 羅什, 344-413), ca. 402-406.

Fayuan zhulin 法苑珠林 [A Forest of Pearls in the Garden of the Dharma], T no. 2122, vol. 53. 100 juan. Compiled by Daoshi 道 
世 (ca. 596-683); completed in 668.

Liumen tuoluoni jing 六門陀羅尼經 [Sūtra on the Six Approach

Dhāraṇī], T no. 1360, vol.21. 1 juan. Translated by Xuanzang 玄 壯 (ca. 602-664).

Miaofa lianbua jing 妙法蓮花經 [Skt. Saddharmapundarika-sütra,

Lotus Sütra], T no. 262, vol. 9. 7 juan. Translated by Kumārajīva

(Jiumoluoshi 鳩摩羅什, 343-413), ca. 406 or 405.

Pusa dichijing 菩薩地持經 [Bodhisattva-bhūmi; The Stages of

the Bodhisattva], T no. 1581, vol. 30.10 juan. Translated by

Dharmakșema (Tanwuchen 曇無識, 385-433) ca. 414-421.

Sheng chuangbeiyin tuoluoni jing 勝幢臂印陀羅尼經 [Sūtra on the

Dhāran̄i for Bearing Banners and Seals], T no. 1363, vol. 21. 1

juan. Translated by Xuanzang 玄娤 (ca. 602-664), ca. 654.

Shidijinglun 十地經論 [Skt. * Daśabbūmika-sūtra-śästra; Treatise on the Sūtra on the Ten Stages], T no. 1522, vol. 26. 12 juan. By

Vasubandhu (Shiqin 世親, 400-480). Translated by Bodhiruci

(Putiliuzhi 菩提流支, fl. 508-540).

Shiyimian Guanshiyin shenzhou jing 十一面觀世音神呪經 [Skt.

* Avalokitesvaraikādaśamukha-dhārañī; Sūtra on the Spirit Spell

of the Eleven-Headed Avalokiteśvara], T no. 1070, vol. 20. 1

juan. Translated by Yaśogupta (Yesheduodao 耶舍崛多).

Shiyimian shenzhou xin jing 十一面神呪心經 [Skt.

* Avalokitesvaraikādaśamukha-dhārañī Sūtra on the Heart of

the Spirit Spell of the Eleven-Headed Avalokiteśvara], $T$ no.

1071, vol. 20. 1 juan. Translated by Xuanzang 玄牀 (602-664)

on April 27, 656, at Da Ci’en si Monastery 大慈恩寺.

Shiyimian Guanzizai pusa xinmiyan niansong yigui jing 十一

面觀自在菩薩心密言念誦儀軌經 [Ritual Manual Sūtra on

the Recitation of the Heart-Mantra of the Eleven-headed

Bodhisattva Avalokiteśvara], T no. 1069, 20. 3 juan. Translated

by Amoghavajra (Bukong 不空, 705-774).

Tuoluoni ji jing 陀羅尼集經 [Skt. *Dhāranìsamuccaya; Dhāran̄ī collection], T no. 901, vol. 18. 12 juan. Translated by Atigupta

(Adiquduo 阿地篗多, fl. seventh century), ca. 654 .

Tuoluoni zaji 陀羅尼雜集 [Dhāraṇi miscellany], T no. 1336, vol. 21.

10 juan. Translator unknown; probably during Liang dynasty (502-557). 
Xu Gaoseng zhuan 續高僧傳 [Further Lives of Eminent Monks (compiled during the Tang)], T no. 2060, vol. 50.30 juan. Compiled by Daoxuan 道宣 (596-667); completed in 649. Yuqie shidi lun 瑜伽十地論 [Skt. Yogācārabhümi; Treatise on Yogācāra stages], T no. 1579, vol. 30. 100 juan. Attributed to Maitreya (Mile 彌勒). Translated by Xuanzang 玄牀 (602-664), ca. 646-648.

Zhou wu shou 咒五首 [Five Spells], T no. 1034, vol. 20. 1 juan.

Translated by Xuanzang 玄壯 (602-664).

Zhufoxin tuoluoni jing 諸佛心陀羅尼經 [Sūtra on the Dhāraṇī of the Heart of All Buddhas]. 1 juan. Translated by Xuanzang 玄牀 (ca. 602-664). T no. 918, vol. 19.

Zongshi tuoluoni yizan 總釋陀羅尼義讚 [Encomia on a general interpretation of the Meaning of Dhāraṇī], T no. 902, vol. 18. 1 juan. Apocryphal text attributed to Amoghavajra (Bukong 不空, 705-774).

\section{Secondary Sources}

Abé, Ryūichi. The Weaving of Mantra: Kükai and the Construction of Esoteric Buddhist Discourse. New York: Columbia University Press, 1999.

Braarvig, Jens. 'Dhāraṇi and pratibhāna: memory and eloquence of the bodhisattvas'. Journal of the International Association of Buddhist Studies 8, no. 1 (1985): 17-29.

Ch'en, Kenneth K. S. Buddhism in China: A Historical Survey. Princeton: Princeton University Press, 1964.

Cort, John E. Jains in the World: Religious Values and Ideology in India. Oxford: Oxford University Press, 2001.

Davidson, Ronald M. 'Studies in Dhāraṇ̄ Literature I: Revisiting the Meaning of the Term Dhärañi'. Journal of Indian Philosophy 37, no. 2 (April 2009): 97-147.

_. 'Studies in Dhārañi Literature II: Pragmatics of dhārañìs'. Bulletin of the School of Oriental and African Studies 77, no. 1 (February 2014): 5-61.

Grinstead, Eric, trans. 'The Sūtra of the Eleven-headed Avalokiteśvara Bodhisattva'. In The Esoteric Buddhist Tradition: Selected Papers 
from the 1989 SBS Conference, edited and with an introduction by Henrik H. Sørensen, 97-125. SBS Monographs 2.

Copenhagen, Aarhus: The Seminar for Buddhist Studies, 1994. Kokusai Bukkyōgaku Daigakuin Daigaku Gakujutsu Furontia Jikkō Iinkai 国際仏教学大学院大学学術フロンティア実行委員会 [International Buddhist Studies Graduate University Academic Frontier Executive Committee], comp. Nihon genzon hasshu issaikyō taishō mokuroku: Shōgozō (shahon) Kongōji issaikyō Nanatsudera issaikyō Ishiyamadera issaikyō Köshōji issaikyō Saibōji issaikyō Natori Shingūji issaikyō Myōrenji zō Matsuosha issaikyō日本現存八種一切経対照目錄: 聖語蔵(写本)、金剛寺一 切経、七寺一切経、石山寺一切経、興聖寺一切経、西方寺一切経、 名取新宮寺一切経、妙蓮寺蔵松尾社一切経 [Concordance of the Eight Currently Extant Buddhist Canon in Japan: Manuscript Canon of Shōgozō, the Kongōji Canon, the Nanatsudera Canon, the Ishiyamadera Canon, the Kōshōji Canon, the Saihōji Canon, the Shingūji Canon in Natori, the Matsuosha Canon stored at the Myōrenji]. Tokyo: Kokusai Bukkyōgaku Daigakuin Daigaku Gakujutsu Furontia Jikkō Iinkai 国際仏教学大学院大学 学術フロンティア実行委員会, 2006.

Kubo, Tsugunari, and Akira Yuyama, trans. Lotus Sūtra (Taishō Volume 9, Number 262). Berkeley: Numata Center for Buddhist Translation and Research, 2007.

Li Rongxi, trans. A Biography of the Tripitaka Master of the Great Cien Monastery of the Great Tang Dynasty. Berkeley: Numata Center for Buddhist Translation and Research, 1995.

McBride, Richard D., II. 'Dhāran̄ī and Spells in Medieval Sinitic Buddhism'. Journal of the International Association of Buddhist Studies 28, no. 1 (2005): 85-114. - 'Practical Buddhist Thaumaturgy: The Great Dhärani on Immaculately Pure Light in Medieval Sinitic Buddhism'. Journal of Korean Religions 2, no. 1 (March 2011): 33-73.

- 'Wish-fulfilling Spells and Talismans, Efficacious Resonance, and Trilingual Spell Books: The Mahāpratisarā-dhārañ̄i in Chosŏn Buddhism'. Pacific World, Third Series, 20 (2018): 55-94. Nattier, Jan. 'The Heart Sütra: A Chinese Apocryphal Text?' Journal of the International Association of Buddhist Studies 15, no. 2 
(1992): 153-223.

Reis-Habito, Maria. 'The Great Compassion Dhāranī'. In The Esoteric Buddhist Tradition: Selected Papers from the 1989 SBS Conference, edited by Henrik H. Sørensen, 31-49. SBS Monographs 2.

Copenhagen, Aarhus: The Seminar for Buddhist Studies, 1994.

Schopen, Gregory. 'Bodhigarbhālañkāralakṣa and Vimaloṣnị̄ṣa

Dhāran̄is in Indian Inscriptions: Two Sources for the Practice of Buddhism in Medieval India'. Wiener Zeitschrift für die Kunde Südasians 39 (1985): 119-49.

—. "The Text of the "Dhāraṇi Stones from Abhayagiriya": A Minor Contribution to the Study of Mahāyāna Literature in Ceylon'. Journal of the International Association of Buddhist Studies 5, no. 1 (1982): 100-08.

Shinohara, Koichi. Spells, Images, and Mandalas: Tracing the Evolution of Esoteric Buddhist Rituals. Sheng Yen Series in Chinese Buddhist Studies. New York: Columbia University Press, 2014. Smith, Frederick M. The Self Possessed Deity and Spirit Possession in South Asian Literature and Civilization. New York, Columbia University Press, 2012.

Sørensen, Henrik. Introduction to 'The Sūtra of the Eleven-headed Avalokiteśvara Bodhisattva', translated by Eric Grinstead. In The Esoteric Buddhist Tradition: Selected Papers from the 1989 SBS Conference, SBS Monographs 2, edited by Henrik H. Sørensen, 97-125. Copenhagen, Aarhus: The Seminar for Buddhist Studies, 1994.

Strickmann, Michel. Chinese Magical Medicine. Edited by Bernard Faure. Stanford: Stanford University Press, 2002.

Takakusu Junjirō 高楠順次郎, and Watanabe Kaigyoku 渡邊海旭, eds. Taishō shinshū daizōkyō 大正新脩大藏經 [Buddhist Canon compiled under the Taishō Era (1912-1926)]. 100 vols. Tokyo: Taishō issaikyō kankōkai 大正一切經刊行會, 1924-1932.

Waley, Arthur. The Real Tripitaka and Other Pieces. London: George Allen and Unwin, Ltd., 1952.

Wong, Dorothy C. 'The Case of Amoghapāśa'. Journal of Inner Asian Art and Archeology 2 (February 2007): 151-58.

Wriggins, Sally Hovey. Xuanzang: A Buddhist Pilgrim on the Silk Road. Boulder: Westview Press, 1996. 